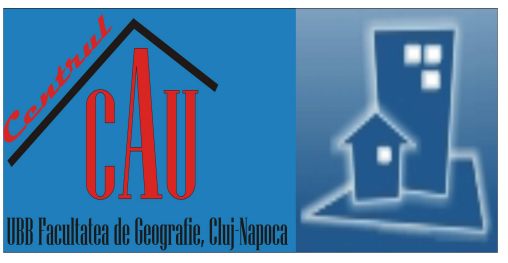

\title{
Mapping Soil Quality in Various Land Uses as a Basis for Soil Management in Wonogiri, Indonesia
}

\author{
Mujiyo MUJIYO**1, Suntoro SUNTORO'1, Restu Prasetyaning TYAS', Aktavia HERAWATI', \\ Hery WIDIJANTO' \\ *Corresponding author \\ ${ }^{1}$ Universitas Sebelas Maret, Faculty of Agriculture, Department of Soil Science, Surakarta, INDONESIA \\ E-mail: mujiyo@staff.uns.ac.id, suntoro@staff.uns.ac.id, restuprasetyaningtyas@gmail.com, aktavia_h@staff.uns.ac.id, \\ herywidijanto@staff.uns.ac.id \\ DOI: 10.24193/JSSP.2020.2.06 \\ https://doi.org/10.24193/JSSP.2020.2.06
}

K e y w o r d s: agricultural intensification, crop field, land degradation, land use, soil management, soil quality index, Indonesia

\begin{abstract}
A B S T RA C T
Soil quality is closely related to environment because soil is not only viewed as a growing media for plants but also encompasses various environmental and health functions. It is important to know the quality of soil in order to keep it healthy, productive, and optimally functioning. This research aims to evaluate soil quality status in various land uses and to learn the land factors that are related to soil quality. Soil quality index (SQI) represents the soil quality status. SQI will then be used as the basis for soil management. A descriptive explorative research study was carried out in the Giritontro Sub-district, Wonogiri District, Indonesia. SQI indicators were obtained from 12 existing Land Mapping Units (LMU). SQI was obtained by determining the Minimum Data Set (MDS) with a Principal Component Analysis (PCA) test. Then SQI was mapped and statistically analyzed to determine the influence of land use and the determinant factors of SQI. Results showed that SQI in all area is class 3 or moderate. SQI was significantly influenced by land use. SQI in paddy field is $9.09 \%$ higher than crop fields and $\mathbf{2 . 2 7 \%}$ higher than of plantations. Indicators which are significantly related to SQI are bulk density, porosity, cation exchange capacity, available $\mathrm{P}$, available $\mathrm{K}$ and microbial biomass carbon (MBC). The type of soil management that can be implemented to improve soil quality includes addition of organic or inorganic fertilizer and adoption of an agroforestry system.
\end{abstract}

\section{INTRODUCTION}

Soil is an important component in the ecosystem, especially in the agriculture sector, because of its function in supplying nutrition. It has the additional function of serving as a place where biological processes occur, including the cycling of soil nutrients, so in agricultural endeavours, soil is not only connected to its physical, chemical, and biological properties but also to the surrounding environment (Suntoro et al., 2020). Soil quality plays a significant role in defining cultivation systems in sustainable farming (Lal, 1994). Knowledge of soil quality status is needed to understand the conditions and processes taking place in the soil in order to ascertain that the soil is capable of carrying out its function properly (Marzaioli et al., 2010). The Soil Science Society of America defines soil quality as the capacity of soil function to sustain plant and animal productivity, maintain or enhance water and air quality, and support human health and habitation (Karlen et al., 1997).

Soil quality index (SQI) represents the status of soil quality. It is an index calculated based on the value and weight of each soil quality indicator. The indicators of soil quality are chosen from the properties that show the capacity of soil function (Partoyo, 2005). Those used in the assessment of SQI include the physical, chemical, and biological properties of the soil. In addition, soil 
type, topography, and land use are other factors that should be taken into consideration in the SQI evaluation for the purpose of advancing the agriculture and plantation sectors (Rasyid, 2004).

However, in practice, farming endeavours often have a negative effect on ecosystems, leading to a decline in soil quality due to agricultural intensification (FAO, 1999). Incorrect land management and land use are the reason of land degradation (Winarno, 2009; Rahman et al., 2012). Land degradation may lead to drought or flooding, which are signs of a hydrological imbalance in watershed areas (Miardini and Susanti, 2016). Giritontro Sub-district is located in Wonogiri District, Indonesia, which is an area often affected by drought. A population of 10,663 local inhabitants was negatively impacted by droughts in 2018 and 2019 (Jawa Pos, 2019). Giritontro Sub-district also has one of the highest levels of erosion risk (Santoso et al., 2017), which is one of the indicators proving an increased level of land degradation.

Sustainable land management is needed to reduce land degradation and improve soil quality. Data about the soil quality in a region is required as the basis for compiling recommendations for land management. Evaluation and monitoring of soil quality is needed to formulate soil and land management recommendations in order to preserve the sustainability of agricultural production (Mujiyo et al., 2016; Mujiyo et al., 2017). SQI values is used to determine the distribution of SQI in a certain area, so that it can be employed for preparing land management recommendations, according to the weaknesses and strengths of each land. This research aims to evaluate of soil quality status in various land uses and to find out which land factors that are related to soil quality. In order to highlight the soil quality related factor it were formulated some recommendations for soil management in this region.

\section{THEORY AND METHODOLOGY}

\subsection{Study area}

This research was conducted in the Sub-district of Giritontro, in the Wonogiri District of Central Java Province, which is located between $8^{\circ} 01^{\prime} 50,6$ "and $8^{\circ} 09^{\prime} 25,7$ " south latitude and between $110^{\circ} 51^{\prime} 19,7$ "and $110^{\circ} 56^{\prime} 15,9$ ' east longitude, with an mean altitude of 195 $\mathrm{m}$ AMSL, and covers an area of 6,163.1590 ha. Most of the land in the research location is used for agricultural cultivation, including paddy fields, plantations, and crop fields. Approximately $76.56 \%$ of land in the Giritontro Sub-district is farmland (BPS, 2017). The geographical conditions are dominated by limestone. The research location is covered by three soil types, namely mollisols, alfisols and inceptisols.

\subsection{Methodology}

The research followed 6 steps: (1) determination of Land Mapping Units (LMUs); (2) field survey; (3) laboratory analysis; (4) determination of Minimum Data Set (MDS); (5) determination of Soil Quality Index (SQI) - mapping of SQI distribution; and (6) statistical analysis. The LMUs were obtained from the results of an overlay of various maps, including soil type maps, slope gradient, rainfall, and land use. The region under study consists of 12 LMUs with 3 repetitions of each (Table 1 and Fig. 1).

Table 1. LMU and its elements in the research area.

\begin{tabular}{c|lccl} 
LMU & \multicolumn{1}{|c}{ Soil type } & $\begin{array}{c}\text { Slope } \\
(\boldsymbol{\%})\end{array}$ & $\begin{array}{c}\text { Rainfall } \\
(\mathbf{m m} / \text { year })\end{array}$ & Land use \\
\hline 1 & Mollisols & $0-8$ & 1,750 & Paddy Field \\
2 & Mollisols & $9-15$ & 2,250 & Paddy Field \\
3 & Alfisols & $0-8$ & 1,750 & Paddy Field \\
4 & Inceptisols & $0-8$ & 1,750 & Paddy Field \\
5 & Mollisols & $0-8$ & 1,750 & Plantation \\
6 & Mollisols & $0-8$ & 2,250 & Plantation \\
7 & Mollisols & $9-15$ & 1,750 & Plantation \\
8 & Mollisols & $26-40$ & 1,750 & Plantation \\
9 & Mollisols & $0-8$ & 1,750 & Crop Field \\
10 & Mollisols & $0-8$ & 2,250 & Crop Field \\
11 & Mollisols & $9-15$ & 1,750 & Crop Field \\
12 & Mollisols & $9-15$ & 2,250 & Crop Field
\end{tabular}

To determine the SQI, the physical, chemical, and biological properties of the soil were observed (Lal, 1994). Soil physical indicators were soil texture (pipette method), bulk density (BD) (clod method) (Blake and Hartge, 1986), cumulative porosity (bulk density 128 comparison method) (Missimer and Lopez, 2018) and water content (gravimetric method). Soil chemical indicators were organic C (Walkey and Black method) (Walkey and Black, 1934), soil pH (pH meter with a soil and water ratio of $1: 10$ ), cation exchange capacity 
(CEC)(extraction $\mathrm{NH}_{4} \mathrm{OAc} 1 \mathrm{~N}$ pH 7), base saturation (BS) (extraction $\mathrm{NH}_{4} \mathrm{OAc} \quad 1 \mathrm{~N} \quad \mathrm{pH} \quad 7$ ), available $\mathrm{K}$ (extraction $\mathrm{NH}_{4} \mathrm{OAc} 1 \mathrm{~N}$ pH 7 ), available $\mathrm{P}$ (Olsen

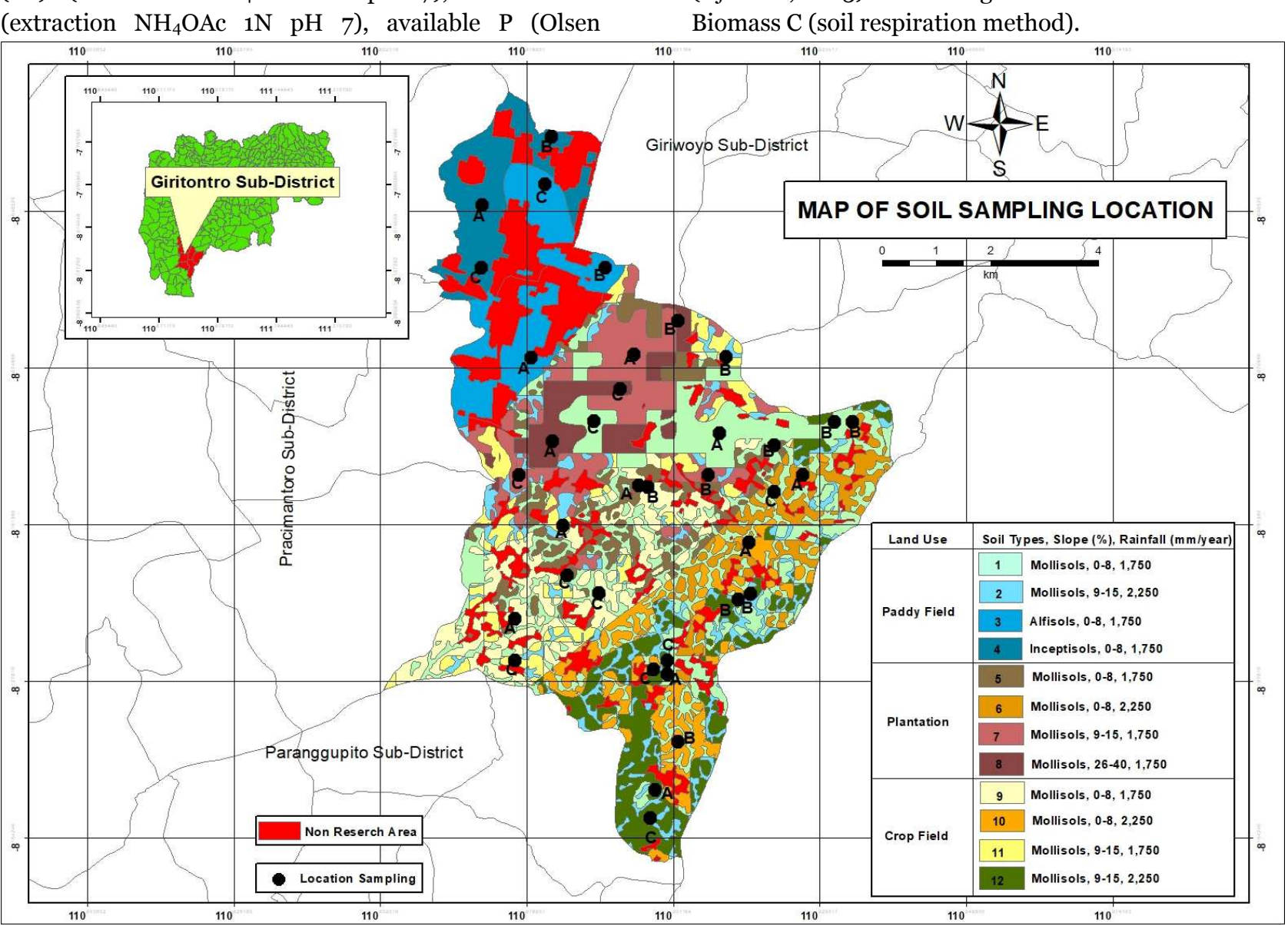

Fig. 1. Soil sampling location.

Soil quality indicator data were analyzed using Principal Components Analysis (PCA) test for MDS determination (Chenet al., 2013) using a statistical application Minitab 19 (Minitab Company, 2019). PCA will produce PC data (principal component) or the main component. The selected PC must have an eigenvalue $\geq 1$ (Chandel et al., 2018). PC data is used to determine the MDS of soil quality.

Soil quality is determined by calculating the value of the SQI, which can be obtained by multiplying the indicator score index $\left(\mathrm{S}_{\mathrm{i}}\right)$ and the weight index $\left(\mathrm{W}_{\mathrm{i}}\right)$ (Mukhopadhyay et al., 2014) using the equation:

$$
S Q I=\sum_{i=1}^{n} W_{i} \times S_{i}^{n}
$$

where :

SQI - soil quality index;

$\mathrm{W}_{\mathrm{i}}$ - weight index (obtained from the result of the PCA test);

$\mathrm{S}_{\mathrm{i}}$ - scoring index of chosen indicator (value of scoring index based on Lal (1994), Andrews (2002), Wander (2002), Balai Penelitian Tanah (2005);

$\mathrm{n}$-number of soil quality indicators.
method)(Olsen et al., 1954), total N (Kjeldahl method) (Kjeldahl, 1883). Soil biological indicator was Microbial Biomass C (soil respiration method). 


\section{RESULTS AND DISCUSSION}

\subsection{SQI mapping}

The results of the PCA analysis showed that there were 3 PCs with an eigen value greater than 1 selected as main components and 5 indicators chosen as the MDS for determining the soil quality value (Table 3 and Fig. 2).

Table 3. Results of the PCA.

\begin{tabular}{l|rrr} 
Eigenvalue & 3.0848 & 2.1000 & 1.4343 \\
Proportion & 0.308 & 0.210 & 0.143 \\
Cumulative & 0.308 & 0.518 & 0.662 \\
\hline Variable & PC1 & PC2 & PC3 \\
\hline BD & 0.276 & $\mathbf{0 . 5 3 1 *}$ & 0.100 \\
Porosity & -0.214 & -0.533 & -0.266 \\
Organic C & 0.063 & 0.294 & -0.649 \\
CEC & $\mathbf{0 . 4 8 7 *}$ & -0.215 & -0.084 \\
BS & -0.429 & $\mathbf{0 . 3 5 7 *}$ & 0.152 \\
Available P & 0.325 & 0.154 & $\mathbf{0 . 3 7 8 *}$ \\
Total N & -0.255 & 0.260 & -0.057 \\
Available K & -0.433 & 0.103 & 0.142 \\
pH & 0.234 & -0.057 & $\mathbf{0 . 3 2 4} *$ \\
MBC & 0.200 & 0.261 & -0.444
\end{tabular}

Note: ${ }^{*}=$ MDS.

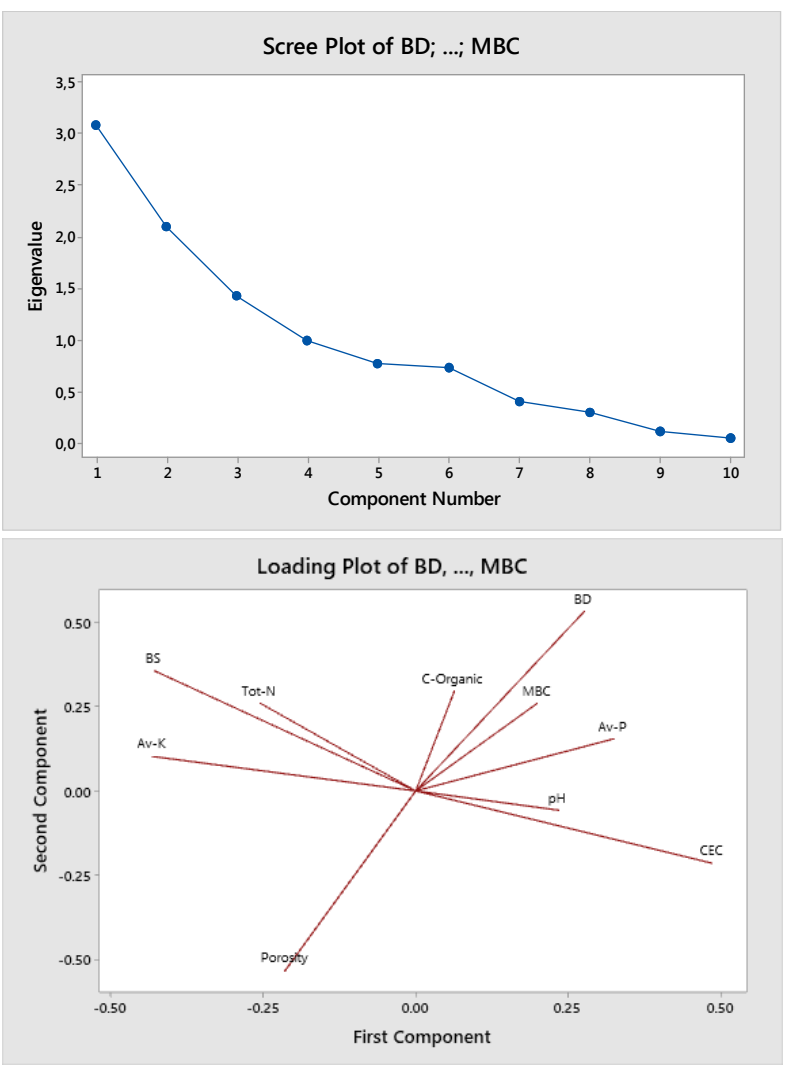

Fig. 2. Results of the PCA.

The chosen indicators had a high level of sensitivity (i.e. representative) in displaying the 130 properties of soil that would be assessed to determine the SQI (Supriyadi, 2018). PC 1 represented 30.8\% of soil quality data and CEC was selected as MDS. Bulk density and base saturation were selected as MDS in PC 2, where both have a high value, but no correlation. Indicators selected as MDS on $\mathrm{PC} 3$ available $\mathrm{P}$ and $\mathrm{pH}$, where both have high values, and no correlation between $\mathrm{pH}$ - available $\mathrm{P}$, but both were maintained as part of the MDS because of its high value.

Table 4. Weight Index of MDS.

\begin{tabular}{|l|rrc}
\multicolumn{1}{c}{ MDS } & Proportion & Cumulative & Wi \\
\hline CEC & 0.308 & 0.662 & 0.465 \\
BS & 0.210 & 0.662 & 0.317 \\
Available P & 0.143 & 0.662 & 0.216 \\
pH & 0.143 & 0.662 & 0.216 \\
BD & 0.210 & 0.662 & 0.317 \\
\hline
\end{tabular}

The SQI values were calculated for the indicators that constituted the MDS by multiplying the $\mathrm{W}_{\mathrm{i}}$ value (Table 4) with the $\mathrm{Si}$ value (Table 5) (Fig. 3).

Table 5. Scoring Index (Si) Values for each LMU.

\begin{tabular}{l|ccccccc}
\multirow{2}{*}{ MDS } & \multicolumn{5}{|c}{ Scoring Index (Si) for each LMU } \\
& $\mathbf{1}$ & $\mathbf{2}$ & $\mathbf{3}$ & $\mathbf{4}$ & $\mathbf{5}$ & $\mathbf{6}$ \\
\hline CEC & 3 & 3 & 3 & 2 & 3 & 2 \\
BS & 3 & 2 & 2 & 3 & 3 & 3 \\
Available P & 1 & 1 & 1 & 1 & 1 & 1 \\
pH & 4 & 4 & 4 & 4 & 4 & 4 \\
BD & 4 & 4 & 4 & 4 & 4 & 4 \\
\hline & Scoring Index (Si) for each LMU \\
& $\mathbf{7}$ & $\mathbf{8}$ & $\mathbf{9}$ & $\mathbf{1 0}$ & $\mathbf{1 1}$ & $\mathbf{1 2}$ \\
\hline CEC & 2 & 2 & 3 & 2 & 2 & 2 \\
BS & 3 & 3 & 2 & 3 & 3 & 3 \\
Available P & 1 & 1 & 1 & 1 & 1 & 1 \\
pH & 4 & 4 & 4 & 4 & 4 & 4 \\
BD & 4 & 4 & 4 & 4 & 1 & 2
\end{tabular}

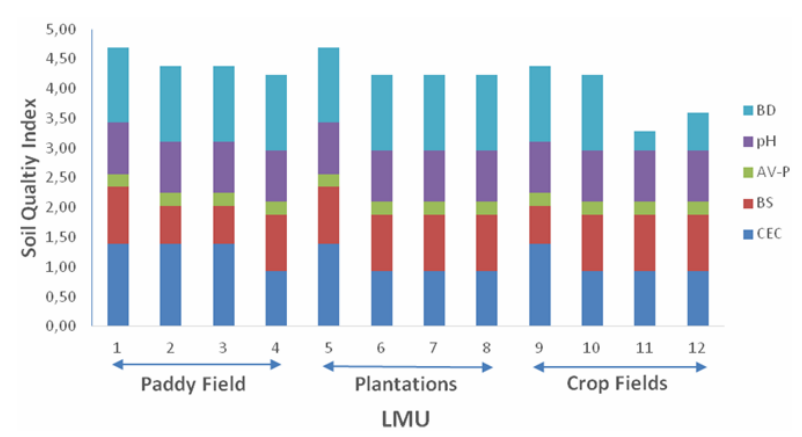
Sub-district.

Fig. 3. Indicator scoring values of SQI in Giritontro

Results of the analysis showed that the SQI values for all LMUs except LMU 11 correspond to class 3 (moderate). SQI values for LMU 11 is included in low class (0.33). SQI values of LMUs with paddy field use (0.44) were higher than LMUs with plantation use (o.43) and crop field use (o.39) (Table 6 and Fig. 4). 
Mapping Soil Quality in Various Land Uses as a Basis for Soil Management in Wonogiri, Indonesia From Linear to Nodal Transport Infrastructure. Case Study: Maramureș County. Romania Journal Settlements and Spatial Planning, vol. 11, no. 21 (2020) 127-135

The combination of LMU elements consisting of Mollisols, a slope gradient of $0-8 \%$, rainfall of 1,750 $\mathrm{mm} /$ year, paddy field land use (LMU 1) and plantation land use (LMU 5) had the highest soil quality value, while a slope gradient of $9-15 \%$ and crop field land use (LMU 11) had the lowest soil quality value.

Table 6. SQI for each LMU.

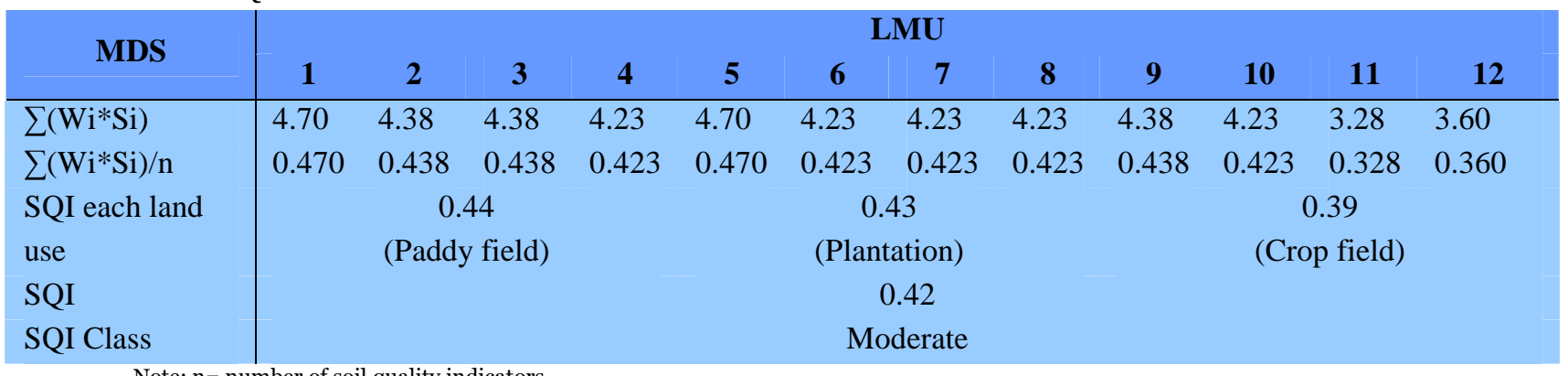

Note: $n=$ number of soil quality indicators.

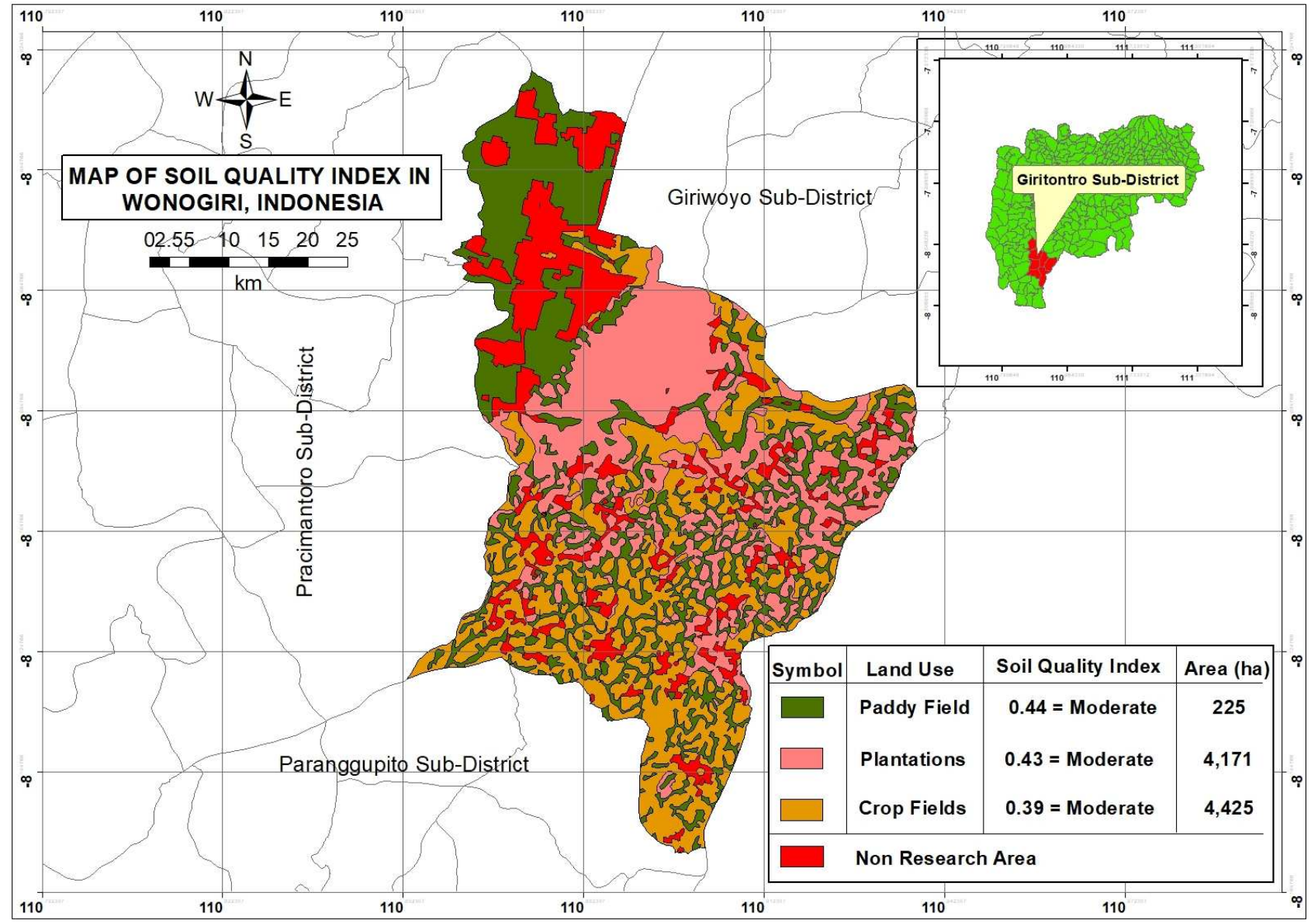

Fig. 4. SQI in several land uses in Giritontro Sub-district.

\subsection{Correlation between SQI and soil indicators}

The results of the One Way ANOVA test show that land use has a significant effect on SQI (F = 7.83; Pvalue $=0.002 ; n=36$ ) (Table 7 ). Land use types affect variations in soil indicators due to differences in land management (Pham et al., 2018; Moges et al., 2013; Girmay et al., 2008; Moges and Holden, 2008). Land use can influence soil quality by altering the physical and chemical properties of the soil (Tematio et al., 2011). Changes to the system of land use can cause long- term and large-scale changes to soil structure and alter microbial activity in the biological process which in turn influences soil quality (Xiao et al., 2017).

In addition to land use, slope gradient ( $\mathrm{F}=$ 9.79; $\mathrm{P}$-value $=0.000 ; \mathrm{n}=36$ ) also has a significant effect on the SQI. Slope gradient is related to erosion risk and landslides, especially in open land that is not covered by vegetation, resulting in a top soil loss (Herawati et al., 2018; Priyono et al., 2018). Slope gradient influences soil washing and transportation, and the slope gradient factor will influence organic material 
content because of the top soil erosion. The factors of soil type $(\mathrm{F}=1.61 ; \mathrm{P}$-value $=0.214 ; \mathrm{n}=36)$ and rainfall $(\mathrm{F}=3.83 ; \mathrm{P}$-value $=0.075 ; \mathrm{n}=36)$ do not have $\mathrm{a}$ significant influence on SQI.

The indicators significantly related to SQI are cation exchange capacity, available $\mathrm{K}$ and $\mathrm{MBC}$, while those very significantly related are bulk density, porosity and available $\mathrm{P}$ (Table 8). Soil bulk density shows how the condition of soil structure is influenced by soil management. Intensity of soil management and clay content in the soil influence soil bulk density (Marlina and Satriawaniqbal, 2014). Soil with a high bulk density can interfere with the movement of plant roots and groundwater (Mujiyo et al., 2020).

Table 7. Result of One-Way ANOVA for SQI in relation with LMU's elements.

\begin{tabular}{|c|c|c|c|c|c|}
\hline \multirow{2}{*}{ Source of variation } & \multirow{2}{*}{ df } & \multirow{2}{*}{ SS } & \multirow{2}{*}{ MS } & \multicolumn{2}{|c|}{ SQI } \\
\hline & & & & F-value & P-value \\
\hline Soil type & 2 & 0.004 & 0.002 & 1.61 & 0.214 \\
\hline Error & 33 & 0.042 & 0.001 & & \\
\hline Total & 35 & 0.046 & & & \\
\hline Slope gradient & 2 & 0.017 & 0.009 & $9.79 *$ & 0.000 \\
\hline Error & 33 & 0.029 & 0.001 & & \\
\hline Total & 35 & 0.046 & & & \\
\hline Rainfall & 1 & 0.004 & 0.004 & 3.83 & 0.075 \\
\hline Error & 34 & 0.042 & 0.001 & & \\
\hline Total & 35 & 0.046 & & & \\
\hline Land use & 2 & 0.015 & 0.007 & $7.83 *$ & 0.002 \\
\hline Error & 33 & 0.032 & 0.001 & & \\
\hline Total & 35 & 0.046 & & & \\
\hline
\end{tabular}

Table 8. Correlation between SQI and indicators.

\begin{tabular}{c|llllllllll} 
& \multicolumn{1}{|c}{ BD } & Por & C-Org & CEC & BS & Av-P & Tot-N & Av-K & pH & MBC \\
\hline SQI & $0.743^{* *}$ & $-0.691^{* *}$ & 0.108 & $0.362^{*}$ & -0.133 & $0.533^{* *}$ & 0.003 & $-0.346^{*}$ & 0.084 & $0.378^{*}$ \\
& 0.000 & 0.000 & 0.531 & 0.030 & 0.439 & 0.001 & 0.987 & 0.038 & 0.626 & 0.023
\end{tabular}

Note: Cell contents $=$ Pearson correlation and P-Value.

* = correlation is significant (at $\mathrm{P}<0.05$ level).

** = correlation is very significant (at $\mathrm{P}<0.01$ level).

The capacity of cation exchange correlates with the ability of soil to make nutrients available to the plants. Soil with a high cation exchange capacity has a potentially high quality because it has the ability to make sufficient nutrients available for the plants. Available $\mathrm{K}$ are essential nutrients needed by plants in large quantities. Phosphorus and potassium are essential macro elements that affect soil fertility and plant growth, so their availability must be considered (Cozzolino et al., 2013; Qiu et al., 2014; Srinivasarao et al., 2014; Sanyal et al. 2015). Wibowo (2013) explains that the increase in microorganism biomass carbon (MBC) indicates an increase in the activity of soil microorganisms. The increased activity of soil microorganisms indicates that the soil has ideal quality. Soil organisms play an important role in the cycle process of nutrients and organic matter (Syamsiyah et al., 2018).

\subsection{Soil management}

Soil management is based on indicators that are significantly related to the SQI and indicators that have a low score. Indicators significantly related to SQI are bulk density, porosity, cation exchange capacity, available $\mathrm{P}$, available $\mathrm{K}$ and $\mathrm{MBC}$. Available $\mathrm{P}$ is one indicator with a low score andvery significantly related to SQI . The soil types in Giritontro Sub-district have a range of very low - low available $\mathrm{P}$ content. Soil with a very low available $\mathrm{P}$ content will interfere with plant growth without the application of additional $\mathrm{P}$ fertilizer (Kusumastuti, 2014).

The application of organic material can increase the $\mathrm{P}$ availability because organic material in the soil serves to replace the anion $\mathrm{H}_{2} \mathrm{PO}_{4}$-in the adsorption site and increases the amount of organic $\mathrm{P}$ that is mineralized to become inorganic $\mathrm{P}$ (Noor, 2003). The $\mathrm{P}$ content can be added by using rice straw biochar (RSB) and rice husk ash (RHA), both of which can increase the available $\mathrm{P}$ and available $\mathrm{K}$ content (Gupta et al., 2019). Singh et al. (2013) state that the addition of RHA and inorganic or organic fertilizer can increase P availability. The addition of superphosphate inorganic fertilizer (SP-36) can also offer an alternative solution for increasing $\mathrm{P}$ availability (Julianto et al., 2019) but the fertilization must follow the recommended dose.

Another alternative recommendation for land management is to choose land use that is appropriate to the land capacity. The analysis revealed that land use has a significant influence on the SQI as well as on most of its indicators. Land use has a significant effect on bulk density, cation exchange capacity, base saturation, available $\mathrm{P}$, available $\mathrm{K}$, and microbial biomass $\mathrm{C}$. The adoption of an agroforestry system is another strategy 
for restoring soil quality. An agroforestry system can improve the physical qualities of the soil, especially in relation to soil aggregate and biological activity (roots and macrofauna). The most suitable system is a multiple cropping agroforestry pattern between annual and seasonal crops (Maroeto, 2017). The presence of trees produces litter which is a source of organic material (Soelaeman and Haryati, 2012). Organic material can help break up the soil, creating space for tiny pores so that the bulk density declines. It also has the ability to increase cation exchange capacity, available $\mathrm{P}$, and available K (Angelova et al., 2013; Suntoro et al., 2018). Wibowo (2013) and Mujiyo et al. (2018) explains that the existence of microbial biomass carbon (MBC) in soil is influenced by the presence of organic material. Supriyadi et al. (2020) also explain that the increasing amount of organic material leads to an increase in the soil microorganism activity.

\section{CONCLUSIONS}

The SQI in Giritontro corresponds to the moderate class (0.42). SQI was significantly influenced by land use. Paddy field has a higher SQI (0.44) than plantation (0.43) and crop field (0.39). The indicators that are significantly related to SQI are cation exchange, available $\mathrm{K}$ and $\mathrm{MBC}$, and indicators that are very significantly related to SQI are available P, bulk density, and porosity. The soil types in Giritontro Sub-District have a range very low - low available $\mathrm{P}$ content. Available $\mathrm{P}$ is very significant related to SQI and has low score. Agricultural endeavours still need to be implemented to increase soil quality and improve soil structure and soil nutrients, especially the available $P$. The use of organic materials alongside inorganic fertilizer can increase the available $\mathrm{P}$ content. The adoption of an agroforestry system could also offer an alternative solution for land management.

\section{ACKNOWLEDGMENTS}

This research study was supported by Universitas Sebelas Maret under the research grant PNBP 2019-2020. We would like to thank Ahmad Norri Prasetyo, Fajar Eko Susilo, Tiara Hardian, Widhi Larasati, and Yosua Yoga Setyawan for their participation in the field survey and laboratory analysis, also Novi Rahmawati Sutopo for her participation in the elaboration of the paper.

\section{REFERENCES}

Andrews S. S., Mitchell J. P., Mancinelli R., Karlen D. L., Hartz T. K., Horwath W. R., Pettygrove G. S., Scow K. M., Munk D. S. (2002), On - farm assessment of soil quality in California's
Central Valley. Agronomy Journal, 94(1), pp. 12-23. DOI: https://doi.org/10.2134/agronj2002.1200

Angelova V. R., Akova V. I., Artinova N. S., Ivanov K. I. (2013), The effect of organic amendments on soil chemical characteristics. Bulgarian Journal of Agricultural Science, 19(5), pp. 958-971

Balai Penelitian Tanah. (2005), Petunjuk Teknis Analisis Kimia Tanah, Tanaman, Air, dan Pupuk. Badan Penelitian dan Pengembangan Pertanian, Departemen Pertanian. Bogor. [In Indonesian]

Blake G. R., Hartge K. H. (1986), Bulk density. In A. Klute (Ed.). Methods of Soil Analysis. Part 1, 2nd ed. Agronomy 9. SoilSci. Soc. Am., Madison, Wisconsin, pp. 363-376

BPS (2017), Kecamatan Giritontro dalam Angka Tahun 2017. BPS Kabupaten Wonogiri. Wonogiri. Jawa Tengah. [In Indonesian]

Cantu M. P., Becker A., Bedano J. C., Schiavo H. F. (2007), Evaluation of soil quality by using indicators and indices. Ct Suelo, 25, pp. 173-178.

Chandel, S., Hadda, M. S. Mahal, A. K. (2018), Soil quality assessment through minimum data set under different land uses of submontane punjab. Communications in Soil Science and Plant Analysis. Taylor \& Francis, 49(6)

Chen Y. D., Wang H. Y., Zhou J. M., Xing L., Zhu B. S., Zhao Y. C., Chen X. Q. (2013), Minimum data set forassessing soil quality in farmland of Northeast China. Pedosphere. 23(5), pp. 564-576.

Cozzolino V., Di Meo V., Piccolo A. (2013), Impact of arbuscular mycorrhizal fungi applications on maize production and soil phosphorus availability. Journal of Geochemical Exploration, 129, pp. 40-44. DOI: https://doi. org/10.1016/j.gexplo.2013.02.006

ESRI (2014), ArcView 3.3 Desktop Help (United Kingdom: Environmental Systems ResearchInstitute, Inc.) FAO (1999), The state of food insecurity on the world. Food and Agriculture Organisation. Rome

Girmay G., Singh B. R., Mitiku H., Borresen T., Lal R. (2008), Carbon stocks in Ethiopian soils in relation to land use and soil management. Land Degradation and Development, 19(4), pp. 351-367. DOI: https://doi.org/10.1002/ldr.844

Gupta R. K., Hussain A., Sooch S. S., Kang J. S., Sharma S., Dheri G. S. (2020), Rice straw biochar improves soil fertility, growth, and yield of rice-wheat system on a sandy loam soil. Experimental Agriculture, 56(1), pp. 118-131. DOI: https://doi.org/ 10.1017/Soo14479719000218

Herawati A., Suntoro Widijanto H., Pusponegoro I., Sutopo N. R., Mujiyo (2018), Soil degradation level under particular annual rainfall at Jenawi District- Karanganyar, Indonesia. IOP Conference Series: Earth and Environmental Science, 129(1). DOI: https://doi.org/10.1088/1755-1315/129/1/ 012010 
Jawa Pos (2019), Enam Desa di Giritontro Terdampak Kekeringan [online]. URL: https://radarsolo.jawapos. com/read/2019/07/09/145254/enam-desa-di-

giritontro-terdampak-kekeringan. Accessed

on 10.07.2020

Julianto E. A., Suntoro S., Dewi W. S., Partoyo P. (2019), Mapping Indigenous Nutrient Status of PostEruption Soil to Support the Fertilization of Rice (Oryza sativa) in the Southern Area of Merapi Mountain, Indonesia. Journal of Settlements and Spatial Planning, 10(1), pp. 29-38. DOI:https://doi.org/ 10.24193/JSSP.2019.1.03

Karlen D. L., Mausbach M. J., Doran J. W., Cline R. G., Harris R. F., Schuman G. E. (1997), Soil quality: a concept, definition, and framework for evaluation (a guest editorial). Soil Science Society of America Journal, 61(1), pp. 4-10. DOI: https://doi.org/ 10.2136/sssaj1997.03615995006100010001x

Kjeldahl J. (1883), Neue Methode zur Bestimmung des Stickstoffs in organischen Körpern. 22(1), pp. 366382. doi:10.1007/bfo1338151

Kusumastuti A. (2014), Dinamika P Tersedia, PH, COrganik Dan Serapan P Nilam (Pogostemon Cablin Benth.) Pada Berbagai Aras Bahan Organik Dan Fosfat Di Ultisols. Jurnal Penelitian Pertanian Terapan, 14(3), pp. 145-151. DOI: http://dx.doi.org/10.25181/.jppt.v14i3. 153

Lal R. (1994), Method And Guidelines for Assesing Sustainable Use of Soil and Water Resource in The Tropic. Soil Management Support Service USDA Soil Conservation Service. Washington.

Marlina A., Satriawaniqbal H. (2014), Pengaruh olah tanah dan pemberian pupuk kandang terhadap sifat fisik tanah dan produksi tanaman jagung. Lentera: Jurnal Ilmiah Sains dan Teknologi, 14(11)

Maroeto, Suntoro W. A., Sutrisno D., Rossyda P. (2017), Net farm income as refl ection of critical land evaluation in welang watershed, Indonesia. Bulgarian Journal of Agricultural Science, 23(5), pp. 826-833.

Marzaioli R., D'Ascoli R., De Pascale R. A., Rutigliano F. A. (2010), Soil quality in a Mediterranean area of Southern Italy as related to different land use types. Applied Soil Ecology, 44(3), pp. 205-212. DOI: https://doi.org/10.1016/j.apsoil. 2009.12.007

Miardini A., Susanti P. D. (2016), Land use management as an effort to mitigate flood in NgawiRegency. Prosiding Geography National Seminar,UMS 2016 (in Indonesian)

Minitab 19 Statistical Software (2019), [Computer software]. State College, PA: Minitab, Inc. (www.minitab.com)

Missimer TM, Lopez O. M. (2018), Laboratory Measurement of Total Porosity in Unconsolidated Quartz Sand by two Integrated Methods. J Geol Geophys 7 : 448. doi: 10.4172/2381-8719.1000448

Moges A., Dagnachew M., Yimer F. (2013), Land use effects on soil quality indicators: a case study of
Abo-Wonsho Southern Ethiopia. Applied and Environmental Soil Science, 2013. DOI: https://doi. org/10.1155/2013/784989

Moges A., Holden N. M. (2008), Soil fertility in relation to slope position and agricultural land use: A case study of Umbulo catchment in southern Ethiopia. Environmental management, 42(5), pp. 753763. DOI: https://doi.org/10.1007/s00267-008-9157-8 Mujiyo M., Rahayu R., Ustiatik R., Anggrahini D. S. (2016), Mapping of Soil Degradation Potency In Paddy Field Wonogiri, Indonesia. Sains Tanah-Journal of Soil Science and Agroclimatology, 13(1), pp. 25-30. DOI: http://dx.doi.org/10.15608\%2Fstjssa.v13i1.481

Mujiyo M., Sumarno S., Sudadi S., Murti R. W. (2020), Assessment of soil degradation in Pitu District, Ngawi Regency. Journal of Degraded and Mining Lands Management, 7(2), pp. 2049-2057. DOI: https:// doi.org/10.15243/jdmlm.2020.072.2049

Mujiyo M., Widijanto H., Herawati A., Rochman F., Rafirman R. (2017), Potensi Lahan untuk Budidaya Pisang di Kecamatan Jenawi Karanganyar. Caraka Tani: Journal of Sustainable Agriculture. 32(2), 142- 148. DOI: http://dx.doi.org/10.20961/carakatani. v32i2.17020

Mujiyo Sunarmianto B. H., Hanudin E., Widada J., Syamsyiah J. (2018), The effect of organic paddy field system to soil properties. IOP Conference Series: Earth and Environmental Science, 122(1). DOI: 10.1088/1755-1315/122/1/012023

Mukhopadhyay S., Maiti S. K., Masto R. E. (2014), Development of mine soil quality index (MSQI) for evaluation of reclamation success: a chronosequence study. Ecological Engineering, 71, pp. 10-20. DOI: https://doi.org/10.1016/j.ecoleng.2014.07.001

Noor A. (2003), Pengaruh Fosfat Alam dan Kombinasi Bakteri Pelarut Fosfat dengan Pupuk Kandang terhadap P Tersedia dan Pertumbuhan Kedelai pada Ultisol. Jurnal Agronomi Indonesia (Indonesian Journal of Agronomy), 31(3). DOI: https://doi.org/10.24831/ jai.v31i3.1477

Olsen S. R., Cole C. V., Watanabe F. S., Dean L. A. (1954), Estimation of available phosphorus in soils by extraction with sodium bicarbonate. USDA Circular Nr 939, US Gov. Print. Office, Washington, D.C.

Partoyo P. (2005), Analisis Indeks Kualitas Tanah Pertanian Di Lahan Pasir Pantai Samas Yogyakarta. Ilmu Pertanian, 12(2), pp. 140-151. URL: http://eprints.upnyk.ac.id/13510/

Pham T. G., Nguyen H. T., Kappas M. (2018), Assessment of soil quality indicators under different agricultural land uses and topographic aspects in Central Vietnam. International Soil and Water Conservation Research,6(4), pp. 280-288. DOI: https:// doi.org/10.1016/j.iswcr.2018.08.001.

Priyono P., Rahayu R., Minardi S., Suntoro S. (2018), Morphology of Landslide Prone of Agriculture Area in the Sub Watershed Samin Upstream Based on 
Landslide Type Used for Considerations of Early Mitigation Model. International Journal of Mechanical Engineering and Technology, 9(7), pp. 462-475

Qiu S., Xie J., Zhao S., Xu X. Hou Y., Wang X., Zhou W., He P., Johnston A. M., Christie P., Jin, J. (2014), Long-term effects of potassium fertilization on yield, efficiency, and soil fertility status in a rain-fed maize systems in the northeast of China. Field crops research, 163, 1-9. DOI: https://doi.org/10.1016/j.fcr. 2014.04.016

Rahman M. M., Harisuseno D., Sisinggih D. (2012), Studi Penanganan Konservasi Lahan Di Sub Das Keduang Das Bengawan Solo Kabupaten Wonogiri. Jurnal Teknik Pengairan, 3(2), pp. 250-257

Rasyid B. (2004), Kualitas Tanah (Soil Quality). Lembaga penerbitan Universitas Hasanuddin Makassar. Sulawesi Selatan. [In Indonesian]

Santoso A. A., Sudarsono B., Sukmono A. (2017), Analisis Pengaruh Tingkat Bahaya Erosi Daerah Aliran Sungai (DAS) Bengawan Solo Terhadap Total Suspended Solid (TSS) di Perairan Waduk Gajah Mungkur. Jurnal Geodesi Undip, 6(4), pp. 463-473

Sanyal S. K., Dwivedi B. S., Singh V. K., Majumdar K., Datta S. C., Pattanayak S. K., Annapurna K. (2015), Phosphorus in relation to dominant cropping sequences in India: chemistry, fertility relations and management options. Current Science, 108(7), pp. 1262-1270

Singh A., Gupta R. K., Singh Y., Thind H. S., Singh B., Singh V. (2013), Effect of Rice Husk Ash and Bagasse Ash on Inorganic Phosphorus Fractions and Available Phosphorus in an Alkaline Soil under Rice (Oryza sativa L.)-Wheat (Triticum aestivum L.) Cropping System. Journal of the Indian Society of Soil Science, 61(3), pp. 258-260

Soelaeman Y., Haryati U. (2012), Soil Physical Properties and Production of Upland Ultisol Soil. AGRIVITA, Journal of Agricultural Science, 34(2), pp. 136-143. DOI: http://doi.org/10.17503/agrivita.v34i2. 122 Srinivasarao C., Kundu S., Ramachandrappa B. K., Reddy S., Lal R., Venkateswarlu B., Sahrawat K. L., Naik R. P. (2014), Potassium release characteristics, potassium balance, and fingermillet (Eleusine coracana G.) yield sustainability in a 27-year long experiment on an Alfisol in the semiarid tropical India. Plant and soil, 374, pp. 315-330. DOI: https://doi.org/10.1007/s11104-013-1877-8

Steel R. G. D., Torrie J. H. (1980), Principles and procedures of statistics, a biometrical approach. Secon edition. McGraw Hill, New York, USA. ISBN 0-07060926-8

Suntoro S., Mujiyo M., Widijanto H., Herdiansyah G. (2020), Cultivation of Rice (Oryza sativa), Corn (Zea mays) and Soybean (Glycine max) Based on Land Suitability. Journal Settlements and Spatial Planning, 11(1), pp. 9-16. DOI: https://doi.org/ 10.24193/JSSP.2020.1.02
Suntoro S., Widijanto H., Suryono, Syamsiyah J., Afinda D. W., Dimasyuri N. R., Triyas V. (2018), Effect of cow manure and dolomite on nutrient uptake and growth of corn (Zea mays L.). Bulgarian Journal of Agricultural Science, 24(6), pp. 1020-1026.

Supriyadi Mustikaningrum I. A., Herawati A., Purwanto Sumani (2018), Soil quality assessment in organic and non organic paddy fields in Susukan, Indonesia. Bulgarian Journal of Agricultural Science, 24(5), pp. 777-784

Supriyadi Pratiwi M. K., Minardi S., Prastiyaningsih N. L. (2020), Carbon Organic Content under Organic and Conventional Paddy Field and its Effect on Biological Activities (A Case Study in Pati Regency, Indonesia). Caraka Tani: Journal of Sustainable Agriculture, 35(1), pp. 108-116. DOI: https://doi.org/10.20961/carakatani.v35i1.34630.

Syamsiyah J., Herawati A., Mujiyo (2018), The potential of arbuscular mycorrhizal fungi application on aggregrate stability in alfisol soil. IOP Conference Series: Earth and Environmental Science, 142(1). DOI: https://doi.org/10.1088/1755-1315/142/1/012045

Tematio P., Tsafack E. I., Kengni, L. (2011), Effects of tillage, fallow and burning on selected properties and fertility status of Andosols in the Mounts Bambouto, West Cameroon. Agricultural Sciences, 2(3), 334. DOI: 10.4236/as.2011.23044

Walkley A., Black I. A. (1934), An examination of the degtjareff method for determining soil organic matter, and a proposed modification of the chromic acid titration method. Soil science, 37(1), pp. 29-38. DOI:10.1097/00010694-193401000-00003

Wander M. M., Walter G. L., Nissen T. M., Bollero G. A., Andrews S. S., Cavanaugh - Grant D. A. (2002), Soil quality: science and process. Agronomy Journal, 94(1), pp. 23-32. DOI: https://doi.org/10.2134/agronj2002.2300

Wibowo Y. S. (2013), Pengaruh Sistem Olah Tanah pada Lahan Alang-alang (Imperata cylindrica) terhadap Biomasa Karbon Mikroorganisme Tanah (C-mik) yang Ditanami Kedelai (Glycine max L) Musim Kedua. Skripsi. Fakultas Pertanian Universitas Lampung. Bandar Lampung.

Winarno J. (2009), Kajian Kerusakan Lahan Sub Das Keduang Di Gunung Kendeng Di Desa Ngadipiro, Kecamatan Nguntoronadi, Kabupaten Wonogiri. Caraka Tani: Journal of Sustainable Agriculture, 24(1), 21-27 (in Indonesian). DOI: https://doi.org/ 10.20961/carakatani.v24i1.14008.

Xiao S., Zhang W., Ye Y., Zhao J., Wang K. (2017), Soil aggregate mediates the impacts of land uses on organic carbon, total nitrogen, and microbial activity in a Karst ecosystem. Scientific Reports, 7, 41402. DOI: https://doi.org/10.1038/srep41402 